\title{
Bacillus thermodenitrificans sp. nov., nom. rev.
}

\author{
P. Luigi Manachini, ${ }^{1}$ Diego Mora, ${ }^{1}$ Giovanna Nicastro, ${ }^{1}$ Carlo Parini, ${ }^{1}$ \\ Erko Stackebrandt, ${ }^{2}$ Rüdiger Pukall ${ }^{2}$ and M. Grazia Fortina ${ }^{1}$
}

Author for correspondence: M. Grazia Fortina. Tel: +3902 239558 30. Fax: +3902 70630829 .
e-mail: grazia.fortina@unimi.it

1 Industrial Microbiology Section - Department of Food Science and Microbiology, University of Milan, 20133 Milan, Italy

2 Deutsche Sammlung für Mikroorganismen und Zellkulturen $\mathrm{GmbH}, 38124$ Braunschweig, Germany

\begin{abstract}
A polyphasic study was performed on 10 soil isolates of thermophilic denitrifying Bacillus strains from different geographical areas. The presence of two main characteristic bands following amplification of the internal transcribed spacer (ITS) region of rrn operons suggests a close relatedness to 'Bacillus thermodenitrificans'. The isolates cluster around two strains of ' $B$. thermodenitrificans' in riboprint and fatty acid analyses, though differences occur at the strain level. Subsequent DNA-DNA reassociation studies including the 10 isolates, 'B. thermodenitrificans' DSM $465^{\top}$ and DSM 466, and Bacillus stearothermophilus ATCC $12980^{\top}$ and Bacillus thermoleovorans ATCC $43513^{\top}$ revealed such a high level of genomic relatedness between the isolates and the DSM strains ( $>73 \%$ similarity) that they must be considered strains of the same taxon. The degree of DNA-DNA similarity between the 12 strains of ' $B$. thermodenitrificans' and the type strains of the other two phylogenetically neighbouring Bacillus species was significantly lower (21-43\% similarity). Based upon phylogenetic, chemotaxonomic and phenotypic evidence, the designation of $B$. thermodenitrificans sp. nov., nom. rev. is proposed. The type strain of $B$. thermodenitrificans is DSM $465^{\top}$.
\end{abstract}

Keywords: Bacillus thermodenitrificans, DNA-DNA hybridization, chemotaxonomy, riboprinting, ITS analysis

\section{INTRODUCTION}

Following extensive phylogenetic analyses, the genus Bacillus has undergone major taxonomic revisions, leading to the establishment of novel genera (Wisotzkey et al., 1992; Shida et al., 1996; Heyndrickx et al., 1998) and the recognition of new affiliations at the level of genera (Ash et al., 1991; Rheims et al., 1999) and species (Sunna et al., 1997), while at the same time the list of species, including thermophilic representatives, has been extended (Manachini et al., 1985; Demharter \& Hensel, 1989; Andersson et al., 1995; Combet-Blanc et al., 1995; Meier-Stauffer et al., 1996; Pettersson et al., 1996). Despite the progress in rapidly recognizing close degrees of strain relatedness through analysis of $16 \mathrm{~S}$ rDNA similarities, species delineation requires additional evidence. A DNADNA similarity of less than about $70 \%$ is the most convincing parameter, but relevant data are missing for strains of 'Bacillus thermodenitrificans' and their

Abbreviation: ITS, internal transcribed spacer. closest phylogenetic neighbours, e.g. the type strains of Bacillus stearothermophilus and Bacillus thermoleovorans (Rainey et al., 1994). The latter species have recently been shown in a polyphasic study to embrace Bacillus kaustophilus, Bacillus thermocatenulatus, 'Bacillus caldolyticus', 'Bacillus caldovelox' and 'Bacillus caldotenax' (Sunna et al., 1997).

Although classified in group II of Klaushofer \& Hollaus (1970) and in group Ia of Walker \& Wolf (1971), 'B. thermodenitrificans' has remained an unvalidated species. However, the result of recent phylogenetic (Rainey et al., 1994), chemotaxonomic (White et al., 1993) and numerical phenetic (Marteinsson et al., 1996) studies suggested that this taxon merits species status.

In a systematic study of 85 aerobic, thermophilic and spore-forming isolates from soils of different geographical areas (Mora et al., 1998), 34 strains (40\%) were shown to be related to ' $B$. thermodenitrificans'. This paper provides genomic, chemotaxonomic and physiological evidence for the validation of the species 'B. thermodenitrificans'. 


\section{METHODS}

Bacterial strains and growth conditions. The strains used in this study have been previously isolated from soil samples of different geographical areas (Mora et al., 1998). The designation and origin of the isolates as well as that of the reference strains used are compiled in Table 1. Strains were routinely maintained at $4{ }^{\circ} \mathrm{C}$ after growth at $55^{\circ} \mathrm{C}$ for $6-12 \mathrm{~h}$ on nutrient agar. For long-term maintenance, cell suspensions were stored at $-80{ }^{\circ} \mathrm{C}$ in broth cultures supplemented with $15 \%(\mathrm{w} / \mathrm{v})$ glycerol.

Phenotypic characterization. All assays were performed in triplicate and repeated when inconsistent results were obtained. Unless otherwise stated, all cultures were incubated at $55^{\circ} \mathrm{C}$ for $1-7 \mathrm{~d}$.

The following characteristics were determined by the methods described by Smith et al. (1952): anaerobic growth in glucose broth, anaerobic production of gas from nitrate, citrate utilization, starch and casein hydrolysis, indole, acetoin and catalase production. Reduction of nitrate was examined using the method of Lanyi (1987). The urease test followed the method as described by Atlas (1993). Utilization of compounds as sole carbon source was tested on agar (in plates) containing $\left(\mathrm{g} \mathrm{l}^{-1}\right):\left(\mathrm{NH}_{4}\right)_{2} \mathrm{HPO}_{4}, 1 ; \mathrm{KCl}, 0 \cdot 2$; $\mathrm{MgSO}_{4}, 0 \cdot 2$; yeast extract, $0 \cdot 2$; bromocresol purple, 0.004; agar, $15 ; \mathrm{pH} 7$, supplemented with $0.5 \%(\mathrm{w} / \mathrm{v})$ of each carbon source sterilized separately. The temperature range for growth was determined in nutrient agar plates incubated at $50,55,60,65,70$ and $75^{\circ} \mathrm{C}$. Growth was recorded daily for up to $4 \mathrm{~d}$. For $\mathrm{pH}$ studies, nutrient broth was used with $\mathrm{pH}$ adjusted from 5 to 11 . Phenol tolerance levels were determined in LB broth supplemented with a phenol concentration ranging from 1 to $25 \mathrm{mM}$.

Determination of $\mathbf{G}+\mathbf{C}$ content of DNA. DNA base composition was determined by the thermal denaturation method described by Marmur \& Doty (1962), using the equation of Owen \& Hill (1979). DNA from Escherichia coli strain B (Sigma) was used as internal standard.

DNA-DNA hybridization method. DNA was isolated and purified as described previously (Manachini et al., 1985). DNA-DNA homology was determined by the optical renaturation rates method (Kurtzman et al., 1979) with a model Response spectrophotometer equipped with Advance Kinetics Graphic Version 1.3 thermoprogrammer (Gilford System, Ciba Corning Diagnostics). For all samples tested the melting temperature $\left(T_{\mathrm{m}}\right)$ was calculated in $5 \times \mathrm{SSC}$, the same salt concentration used for the determination of DNA-DNA similarities. The temperature of hybridization was $25^{\circ} \mathrm{C}$ below the $T_{\mathrm{m}}$ calculated previously. The equation of Seidler \& Mandel (1971) was used to calculate the extent of DNA-DNA reassociation.

Plasmid detection. Detection of plasmid DNA followed the alkaline extraction procedure described by Sambrook et al. (1989).

Riboprinting. Ribotyping was performed on $B$. thermoleovorans DSM 5366 ${ }^{\mathrm{T}}$, B. kaustophilus DSM 7263, B. stearothermophilus DSM $22^{\mathrm{T}}$, 'B. thermodenitrificans' DSM $465^{\mathrm{T}}$ and 466, and 10 soil isolates as described by Allerberger \& Fritschel (1999). Analysis was done with the RiboPrinter Microbial Characterization System (Qualicon, DuPont) (Bruce, 1996). Each sample lane was normalized to a standard marker set, characterized and identified using similarity measurements to previously run strains and reference patterns. Binary similarity values of riboprint patterns were used to generate an average linkage clustering dendrogram (Sneath \& Sokal, 1973). The reproducibility of the analysis was tested by comparing the riboprint pattern obtained from freshly grown strains and from frozen cultures of the same strains after different times. The patterns obtained were comparable both in the distribution (number and position of bands) and in the intensity of fragments generated.

Internal transcribed spacer (ITS) fingerprints. These experiments were performed as previously described (Mora et al., 1998). Primer set C (forward primer 5'-GTCGTAACAAGGTAGCCGTA-3' and reverse primer 5'-CAAGGCATCCACCGT-3') was used to amplify the region between the $16 \mathrm{~S}$ and $23 \mathrm{~S}$ rDNA genes. The reproducibility of the methods was tested by comparing the amplified pattern of several amplification reactions and also using template DNA as purified for the DNA-DNA reassociation experiments.

Table 1. Strains of ' $B$. thermodenitrificans' isolated from soil and reference strains used in this study

\begin{tabular}{|ll|}
\hline Strain & \multicolumn{1}{c|}{ Origin } \\
\hline TH6A & New isolate from People's Republic of China \\
TH8A & New isolate from People's Republic of China \\
TH4B & New isolate from People's Republic of China \\
TH45A & New isolate from Czech Republic \\
TH33A & New isolate from Sardinia, Italy (= DSM 13147) \\
TH35A & New isolate from Bali, Indonesia (= DSM 13148) \\
TH51A & New isolate from Harvey Bay, Australia \\
TH61A & New isolate from Java, Indonesia \\
BI5A & New isolate from Saudi Arabia (= DSM 13149) \\
TU6F3 & New isolate from Turkey \\
'B. thermodenitrificans' & DSM 465 \\
B. thermodenitrificans & DSM 466 \\
B. thermothermophilus & ATCC $12980^{\mathrm{T}}=$ DSM $22^{\mathrm{T}}$ \\
\hline
\end{tabular}


Cellular fatty acid composition. Analyses of fatty acid composition followed the methods described by Reischl et al. (1998)

Detection of endonuclease activity. The strains were screened for endonuclease activity as described by Zahner \& Priest (1997). The endonuclease assay consisted of testing different aliquots of extract with $2 \mu \mathrm{g}$ substrate ( $\lambda$ DNA and $\mathrm{pBR} 322$ ) in a total volume of $50 \mu \mathrm{l}$. Different buffers (low-, medium-, high-salt) and different incubation temperatures (37, 45, $55^{\circ} \mathrm{C}$ ) were assayed.

\section{RESULTS AND DISCUSSION}

Ten representative strains were selected from the 34 strains previously shown on the basis of $r r n$ spacer polymorphism to cluster with ' $B$. thermodenitrificans' DSM $465^{\mathrm{T}}$ and DSM 466 (Klaushofer \& Hollaus, 1970), apart from the type strains of B. stearothermophilus and B. thermoleovorans. Although it has already been suggested by Rainey et al. (1994) on the basis of $16 \mathrm{~S}$ rDNA similarity values that ' $B$. thermodenitrificans' constitutes an individual phylogenetic lineage, no attempts have been made to validate this species. The isolation of strains which genomically resemble ' $B$. thermodenitrificans' initiated this study which leads to the validation of the species.

Rainey et al. (1994) demonstrated that ' $B$. thermodenitrificans' could be considered a separate taxon, with B. stearothermophilus and B. thermoleovorans showing less than $98.7 \%$ 16S rDNA similarity with strain DSM $465^{\mathrm{T}}$. Our data, obtained by comparison of the published 16S rDNA sequences of ' $B$. thermodenitrificans' DSM $465^{\mathrm{T}}$ with those contained in other databases, using the WU-BLASTN program, also confirmed B. stearothermophilus and B. thermoleovorans to be the neighbouring species, with identities ranging from 97 to $98 \%$. For this reason, in this study ' $B$. thermodenitrificans' strains were only compared with the two most closely related thermophilic bacilli.

As reported previously (Mora et al., 1998), 'B. thermodenitrificans' can be differentiated from other thermo-

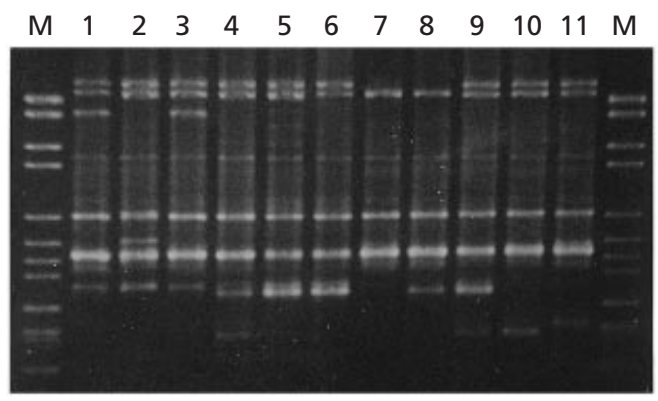

Fig. 1. ITS patterns of ' $B$. thermodenitrificans' strains studied. Lanes: 1-11, DSM 465 ${ }^{\top}, T H 8 A, T H 51 A, T H 6 A, T H 35 A, T H 33 A$, TH61A, TH45A, TU6F3, BI5A, TH4B, respectively; M, molecular mass marker VI $(2176,1766,1230,1033,653,517,453,394,298$, 234, 220, 154 bp; Boehringer Mannheim).

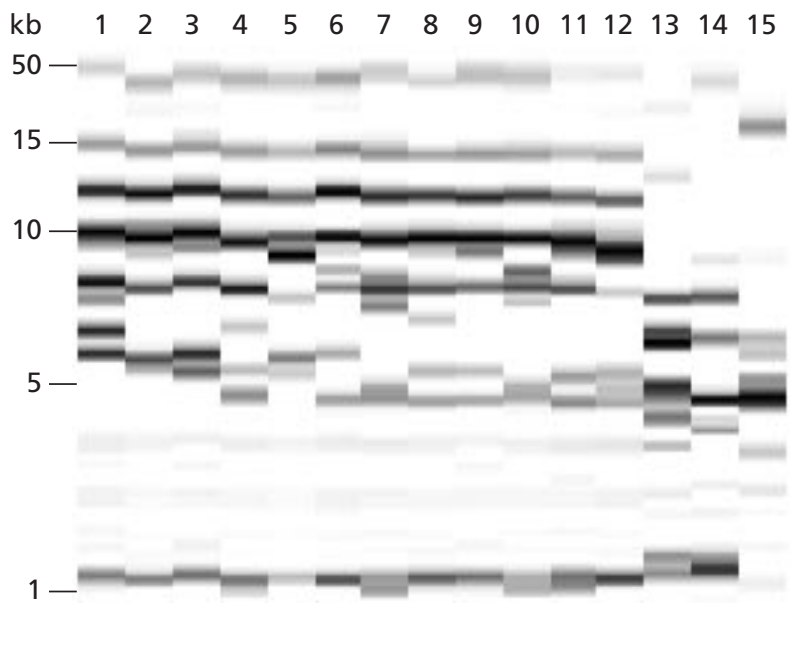

Fig. 2. Diversity of normalized ribotype patterns found within isolates related to strains of ' $B$. thermodenitrificans' and ribotype patterns of the type strains of $B$. stearothermophilus and $B$. thermoleovorans. Lanes 1-15, ' $B$. thermodenitrificans' DSM 466, TH61A, DSM 465' ${ }^{\top}$ TH6A, TH51A, TH4B, TH33A, BI5A, TH45A, TH35A, TU6F3, TH8A, B. kaustophilus DSM 7263, B. thermoleovorans DSM $5366^{\top}, B$. stearothermophilus DSM $22^{\top}$, respectively.

philic Bacillus species by a distinctive pattern of PCR fragments, generated with $16 \mathrm{~S}-23 \mathrm{~S}$ rDNA spacerspecific primers. The banding patterns of the isolates (Fig. 1) were characterized by the presence of two main amplification products of about 625 and $450 \mathrm{bp}$ that should be considered specific and distinctive for the species. Additional fragments ranging from 200 to $500 \mathrm{bp}$ and greater than $1750 \mathrm{bp}$ were present, allowing the characterization of the isolates at the strain level. However, the observed polymorphism did not reflect the geographical origin and did not appear consistent with the phenotypic traits tested.

Analysis of $r r n$ operons was extended by ribotyping, which included the hybridization of separated EcoRIgenerated DNA fragments with a labelled rrn operon probe and visualization of the labelled fragments by a fully automated procedure. The riboprint patterns generated (Fig. 2) were used by the RiboPrint system to calculate binary similarity values which in turn were used to construct a dendrogram of relatedness (Fig. 3). Also, ribotyping provided a powerful means of typing these bacteria at the species and strain levels. Indeed, all isolates cluster around the two strains of ' $B$. thermodenitrificans', while the reference strains of $B$. stearothermophilus and $B$. thermoleovorans branch separately. The depth of the 'B. thermodenitrificans' cluster is comparable to that of $B$. thermoleovorans, indicating that these two taxonomic units exhibit a significant degree of difference in the genomic organization and/or in the sequence of their $\mathrm{rrn}$ operons. Moreover, within the species, the strains displayed some differences in their ribopattern that could be useful in strain characterization. 


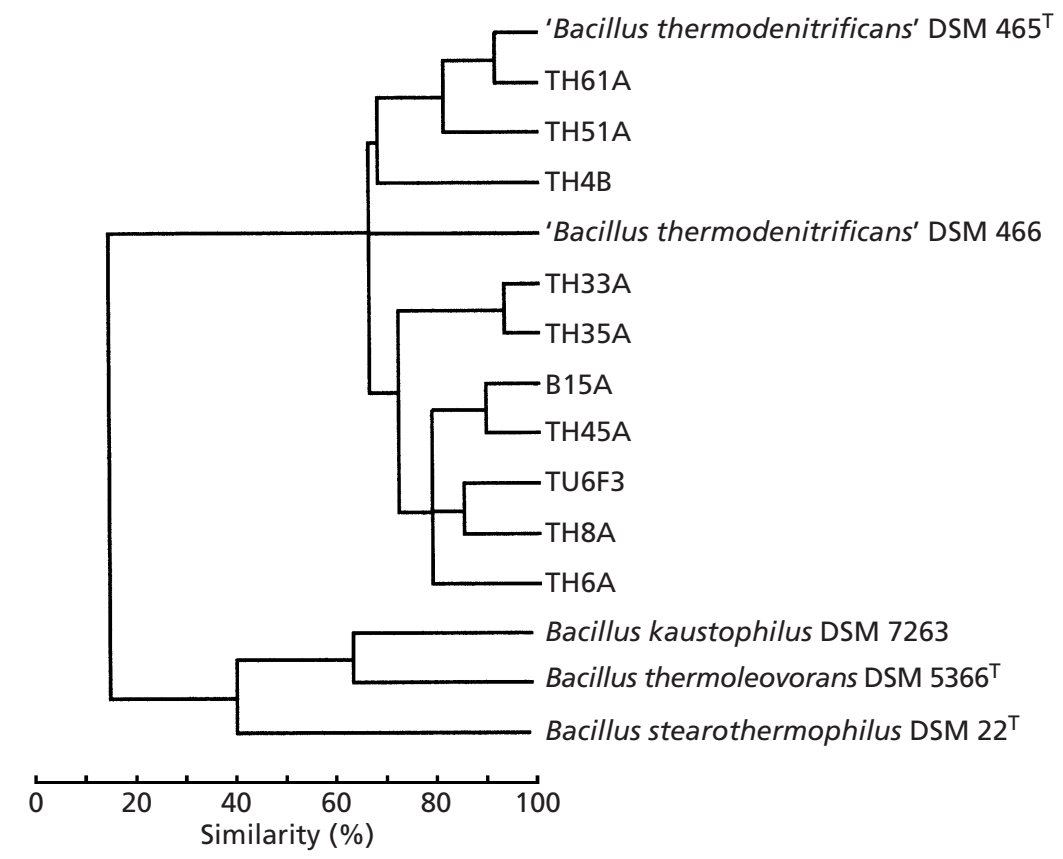

Fig. 3. Dendrogram of relationship based upon similarity of average linkage clustering of ribotype pattern (Fig. 2).

Table 2. Percentage cellular fatty acid composition of some ' $B$. thermodenitrificans' isolates and the reference strains

\begin{tabular}{|c|c|c|c|c|c|c|c|c|}
\hline Fatty acid & $\begin{array}{c}\text { 'B. thermodenitrificans' } \\
\text { DSM } 465^{\mathrm{T}}\end{array}$ & $\begin{array}{c}\text { 'B. thermodenitrificans' } \\
\text { DSM } 466\end{array}$ & TH33A & TH35A & BI5A & TU6F3 & $\begin{array}{l}\text { B. stearothermophilus } \\
\text { ATCC } 12980^{\mathrm{T}}\end{array}$ & $\begin{array}{l}\text { B. thermoleovorans } \\
{\text { ATCC } 43513^{\mathrm{T}}}\end{array}$ \\
\hline iso-14:0 & $0 \cdot 38$ & $0 \cdot 37$ & $0 \cdot 46$ & $0 \cdot 37$ & $0 \cdot 48$ & - & - & $0 \cdot 45$ \\
\hline $14: 0$ & $0 \cdot 41$ & 0.67 & 0.53 & $0 \cdot 48$ & 0.88 & 0.72 & $1 \cdot 32$ & $1 \cdot 15$ \\
\hline iso- $15: 0$ & 35.64 & 37.83 & 37.68 & $36 \cdot 02$ & 36.88 & $37 \cdot 60$ & $33 \cdot 46$ & $38 \cdot 28$ \\
\hline anteiso-15:0 & $1 \cdot 28$ & $1 \cdot 39$ & 1.55 & 1.42 & 1.60 & 1.55 & $4 \cdot 14$ & $2 \cdot 14$ \\
\hline $15: 0$ & 1.79 & $1 \cdot 34$ & 1.88 & 1.63 & 1.81 & $2 \cdot 25$ & - & 0.56 \\
\hline iso- $16: 0$ & 8.07 & $8 \cdot 26$ & 8.57 & 8.38 & 8.53 & $7 \cdot 05$ & $6 \cdot 43$ & $7 \cdot 51$ \\
\hline $16: 0$ & $6 \cdot 77$ & $8 \cdot 50$ & 7.53 & 7.66 & $10 \cdot 79$ & $10 \cdot 43$ & $17 \cdot 35$ & $8 \cdot 45$ \\
\hline iso- $17: 1 \omega 5 c$ & 0.98 & 1.26 & $0 \cdot 70$ & 0.79 & $0 \cdot 32$ & - & - & $2 \cdot 39$ \\
\hline iso- $17: 0$ & $34 \cdot 23$ & $30 \cdot 00$ & 30.99 & 32.58 & $29 \cdot 48$ & $30 \cdot 98$ & $21 \cdot 52$ & $26 \cdot 11$ \\
\hline anteiso-17:0 & $6 \cdot 40$ & 5.83 & $6 \cdot 61$ & 6.69 & 5.97 & $7 \cdot 08$ & $12 \cdot 65$ & 6.94 \\
\hline $17: 0$ & $1 \cdot 61$ & 1.27 & $1 \cdot 35$ & 1.52 & $1 \cdot 17$ & 1.74 & - & $0 \cdot 35$ \\
\hline iso- $18: 0$ & $0 \cdot 34$ & $0 \cdot 37$ & $0 \cdot 29$ & $0 \cdot 35$ & $0 \cdot 30$ & 0.61 & 1.75 & - \\
\hline $18: 0$ & 0.55 & 0.68 & $0 \cdot 48$ & 0.66 & 0.65 & - & - & 0.64 \\
\hline iso- $19: 0$ & 0.74 & 0.85 & $0 \cdot 67$ & 0.69 & $0 \cdot 67$ & - & - & - \\
\hline Others & 0.81 & $1 \cdot 38$ & 0.71 & 0.76 & $0 \cdot 47$ & - & 1.38 & $5 \cdot 03$ \\
\hline
\end{tabular}

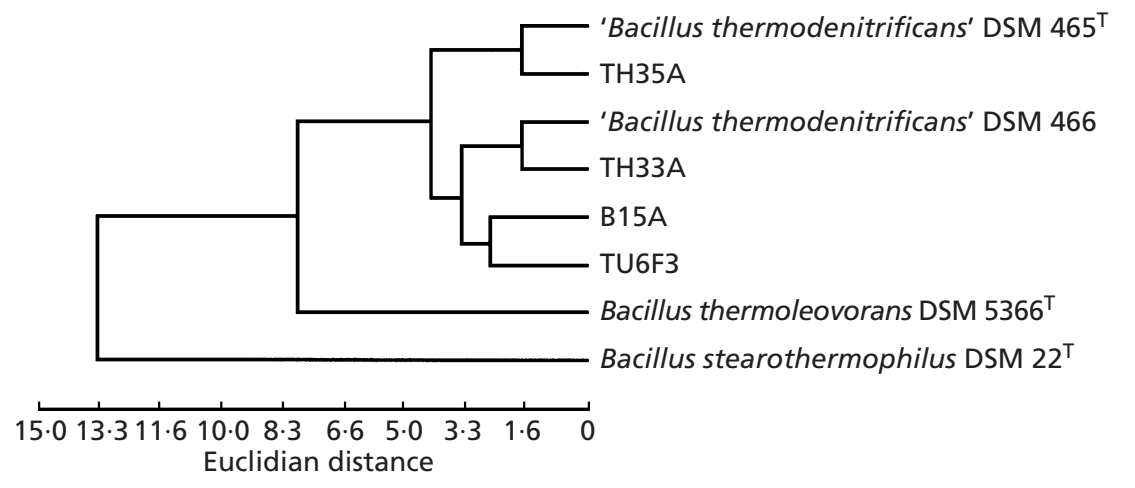

Fig. 4. Dendrogram of fatty acid similarities (Euclidian distance) based on data of strains shown in Table 2.

A similar picture is seen from the analysis of cellular fatty acids (Table 2 and Fig. 4). The principal fatty acids are iso-15:0 and iso-17:0, accounting for
66-69\% of total fatty acids, followed by iso- $16: 0$, 16:0 and anteiso-17:0, accounting for about 8.0, 7.5 and $6.5 \%$, respectively. Differences in the levels of 
Table 3. $G+C$ content of the new ' $B$. thermodenitrificans' isolates and the reference strains tested and DNA-DNA homology with ' $B$. thermodenitrificans' DSM $465^{\top}$

\begin{tabular}{|lcc|}
\hline Strain & G+C (mol \%) & $\begin{array}{c}\text { Percentage DNA homology } \\
\text { with strain DSM 465 }\end{array}$ \\
\hline 'B. thermodenitrificans' DSM 465 & & $(100)$ \\
'B. thermodenitrificans' DSM 466 & $50 \cdot 3$ & 98 \\
TH6A & $51 \cdot 2$ & 94 \\
TH8A & $48 \cdot 6$ & 91 \\
TH4B & $48 \cdot 4$ & 74 \\
TH45A & $50 \cdot 5$ & 93 \\
TH33A & $52 \cdot 3$ & 88 \\
TH35A & $48 \cdot 6$ & 91 \\
TH51A & $51 \cdot 3$ & 73 \\
TH61A & $52 \cdot 3$ & 79 \\
BI5A & $50 \cdot 3$ & 87 \\
TU6F3 & $49 \cdot 2$ & 87 \\
B. stearothermophilus ATCC $12980^{\mathrm{T}}$ & $48 \cdot 2$ & 43 \\
B. thermoleovorans ATCC $43513^{\mathrm{T}}$ & $50 \cdot 7$ & 21 \\
\hline
\end{tabular}

\section{Table 4. Phenotypic characteristics of the new isolates and reference strains used in this study}

Symbols: +, positive; -, negative; w, weak reaction. All isolates and reference strains were positive for the following tests: Gram reaction, catalase, production of gas from nitrate, nitrate reduction, utilization of glucose, fructose, maltose, trehalose, mannose. They were all negative in the following reactions: indole and urease production; Voges-Proskauer.

\begin{tabular}{|c|c|c|c|c|c|c|c|c|c|c|c|c|c|c|}
\hline Characteristic & $\begin{array}{c}\text { 'B. thermo- } \\
\text { denitrificans' } \\
\text { DSM } 465^{\mathrm{T}}\end{array}$ & $\begin{array}{c}\text { 'B. thermo- } \\
\text { denitrificans' } \\
\text { DSM } 466\end{array}$ & TH6A & TH8A & TH4B & TH45A & TH33A & TH35A & TH51A & TH61A & BI5A & TU6F3 & $\begin{array}{c}\text { B. stearo- } \\
\text { thermophilus } \\
\text { ATCC 12980 }^{\mathrm{T}}\end{array}$ & $\begin{array}{c}\text { B. thermo- } \\
\text { leovorans } \\
\text { ATCC } 43513^{\mathrm{T}}\end{array}$ \\
\hline Growth at $45^{\circ} \mathrm{C}$ & + & + & $\mathrm{w}$ & $\mathrm{w}$ & + & $\mathrm{w}$ & + & w & $\mathrm{w}$ & - & - & w & w & - \\
\hline Growth at $70^{\circ} \mathrm{C}$ & + & + & + & + & - & + & - & + & + & + & + & + & - & + \\
\hline Growth at pH 9 & - & + & - & - & - & - & - & + & - & - & - & - & - & - \\
\hline $\mathrm{NaCl}(3 \%)$ & + & + & + & + & + & + & + & + & + & + & + & + & + & - \\
\hline Denitrification & $\mathrm{w}$ & + & + & + & + & + & + & + & + & + & + & + & - & - \\
\hline Anaerobic growth & + & + & $\mathrm{w}$ & + & $\mathrm{w}$ & + & + & - & $\mathrm{w}$ & - & + & $\mathrm{w}$ & w & w \\
\hline Hydrolysis of casein & $\mathrm{w}$ & - & - & - & - & - & w & - & $\mathrm{w}$ & - & + & - & + & $\mathrm{w}$ \\
\hline Hydrolysis of starch & + & w & $\mathrm{w}$ & $\mathrm{w}$ & w & + & + & + & + & + & w & - & + & + \\
\hline \multicolumn{15}{|l|}{ Utilization of: } \\
\hline Rhamnose & - & - & - & - & + & $\mathrm{w}$ & - & $\mathrm{w}$ & $\mathrm{w}$ & - & w & $\mathrm{w}$ & - & - \\
\hline Lactose & + & + & + & + & + & + & + & + & + & + & + & + & - & - \\
\hline Cellobiose & + & + & + & + & + & + & + & + & + & + & + & + & - & + \\
\hline Galactose & + & + & + & + & + & + & + & + & + & + & + & + & - & + \\
\hline Xylose & + & + & + & + & + & + & + & + & + & + & + & + & - & + \\
\hline Ribose & + & + & + & + & + & + & + & + & + & + & + & + & - & + \\
\hline Arabinose & + & + & + & + & w & + & + & + & + & w & + & + & - & - \\
\hline Citrate & - & + & $\mathrm{w}$ & w & - & + & $\mathrm{w}$ & w & + & - & + & $\mathrm{w}$ & - & w \\
\hline Phenol resistance (mM) & 20 & 15 & 20 & 10 & 15 & 20 & 10 & 15 & 20 & 20 & 20 & 15 & 20 & 15 \\
\hline
\end{tabular}

16:0, iso-17:0, anteiso- $15: 0$ and anteiso- $17: 0$, as well as the presence of minor amounts of $15: 0$ and $17: 0$ differentiate strains of the ' $B$. thermodenitrificans' taxon from the type strain of B. stearothermophilus. The differences between strains of ' $B$. thermodenitrificans' and the type strain of B. thermoleovorans are less substantial. A dendrogram of fatty acid relationships shows four soil isolates clustering with strains of ' $B$. thermodenitrificans' and this group is separate from the reference strains of the two thermophilic Bacillus species (Fig. 4).

Analysis of the base composition of DNA (Table 3) revealed that all soil isolates and the two strains of ' $B$. thermodenitrificans' exhibit similar values ranging from 48.4 to $52.5 \mathrm{~mol} \% \mathrm{G}+\mathrm{C}$. Both DSM strains of ' $B$. thermodenitrificans' have very similar values $(50 \cdot 3$ and $51.2 \mathrm{~mol} \%$ ) in accordance with their phylogenetic and chemotaxonomic closeness. This contradicts the finding of Pichinoty et al. (1978) who reported a difference of $11 \mathrm{~mol} \%$ in the $\mathrm{G}+\mathrm{C}$ content of these two strains.

DNA-DNA reassociation studies were performed to determine whether the thermophilic soil isolates were members of the taxon ' $B$. thermodenitrificans' and whether this taxon was genomically distinct enough to warrant its description as a new species. Using DNA of 
strain DSM $465^{\mathrm{T}}$ as a reference, similarity values of soil isolates and DSM 466 ranged between 73 and $94 \%$, while only low relatedness was found with the type strains of B. stearothermophilus (ATCC $12980^{\mathrm{T}}=$ DSM $22^{\mathrm{T}}$ ) and B. thermoleovorans (ATCC $43513^{\mathrm{T}}=$ DSM 5366 ${ }^{\mathrm{T}}$ ) (43 and $21 \%$ similarity, respectively) (Table 3). These data show that the taxon ' $B$. thermodenitrificans' is genetically rather homogeneous and well differentiated from the other two species.

The main phenotypic characteristics are reported in Table 4. All properties listed in the literature for ' $B$. thermodenitrificans' were confirmed. The strains were positive for the following tests: Gram reaction, catalase, growth at $65^{\circ} \mathrm{C}$, growth in presence of $3 \%$ $\mathrm{NaCl}$, nitrate and nitrite reduction to gas, anaerobic production of gas from nitrate, and utilization of glucose, fructose, maltose, trehalose, mannose, lactose, cellobiose, galactose, xylose, ribose and arabinose. The strains were resistant to phenol concentrations of 10-20 mM. They were negative for the following reactions: indole and urease production, and the Voges-Proskauer test (acetylmethylcarbinol production). No strain produced endonuclease activity. Extrachromosomal elements were not found. Strains varied in the following tests: growth at $\mathrm{pH} \mathrm{9,} \mathrm{anaerobic}$ growth in glucose broth, hydrolysis of casein and starch, and utilization of rhamnose and citrate. In addition to the denitrification property, sufficient phenotypic differences existed between the ' $B$. thermodenitrificans' strains and the type strains of B. stearothermophilus and $B$. thermoleovorans to support the proposal of a new species. Even if the ability to reduce nitrate to gaseous compounds occurs among some strains of $B$. stearothermophilus and $B$. thermoleovorans (data not shown), 'B. thermodenitrificans' differs from $B$. stearothermophilus in the ability to utilize a larger number of carbon sources, and from $B$. thermoleovorans in the utilization of lactose and arabinose and growth in presence of $3 \% \mathrm{NaCl}$.

The results of this polyphasic study support the proposal of a new Bacillus species for which the invalid epithet thermodenitrificans (Klaushofer \& Hollaus, 1970) is maintained.

Three new isolates have been deposited in the DSMZ with the following accession numbers: strain TH33A $=$ DSM 13147; strain TH35A = DSM 13148; strain $\mathrm{BI} 5 \mathrm{~A}=\mathrm{DSM} 13149$.

\section{Description of Bacillus thermodenitrificans (ex Klaushofer and Hollaus 1970) sp. nov., nom. rev.}

Bacillus thermodenitrificans (ther.mo.de.ni.tri'fi.cans. Gr. n. therme heat; M.L. part. adj. denitrificans denitrifying; thermodenitrificans thermophilic denitrifying, referring to two of the main characteristics).

Gram-positive, straight rods $0.5-1 \times 1.5-2.5 \mu \mathrm{m}$; endospores are oval, subterminal or terminal, not distending the sporangium. Colonies are flat with lobate margins and off-white to beige. Growth occurs at $50-65^{\circ} \mathrm{C}$ and some strains, including the type strain, are capable of growth at 45 and $70^{\circ} \mathrm{C}$. The optimum $\mathrm{pH}$ values for growth are from 6 to 8 . Positive for catalase, growth in presence of $3 \% \mathrm{NaCl}$, nitrate and nitrite reduction to gas and anaerobic production of gas from nitrate. Most strains are able to hydrolyse starch and a few degrade casein weakly. Negative for indole and urease production and Voges-Proskauer reaction. Glucose, fructose, maltose, trehalose, mannose, lactose, cellobiose, galactose, xylose, ribose and arabinose are utilized as sole carbon sources. The strains are resistant to phenol concentrations of 10-20 mM. The main fatty acids are iso-15:0 and iso17:0; minor acids are 16:0, iso-16:0 and anteiso-17:0. The $\mathrm{G}+\mathrm{C}$ content is $48 \cdot 2-52 \cdot 3 \mathrm{~mol} \%$. The natural habitat is soil. The type strain is DSM $465^{\mathrm{T}}$.

\section{ACKNOWLEDGEMENTS}

This research was supported by a grant from the Ministry of the University and Technological and Scientific Research (MURST $40 \%$ ).

\section{REFERENCES}

Allerberger, F. \& Fritschel, S. J. (1999). Use of automated ribotyping of Austrian Listeria monocytogenes isolates to support epidemiological typing. J Microbiol Methods 35, 237-244.

Andersson, M., Laukkanen, M., Nurmiaho-Lassila, E.-L., Rainey, F. A., Niemela, S. I. \& Salkinoja-Salonen, M. (1995). Bacillus thermosphaericus sp. nov. A new thermophilic ureolytic Bacillus isolated from air. Syst Appl Microbiol 18, 203-220.

Ash, C., Farrow, J. A. E., Wallbanks, S. \& Collins, M. D. (1991). Phylogenetic heterogeneity of the genus Bacillus as revealed by comparative analysis of small-subunit-ribosomal RNA sequences. Lett Appl Microbiol 13, 202-206.

Atlas, R. M. (1993). In Handbook of Microbiological Media, p. 967. Edited by L. C. Park. London: CRC Press.

Bruce, J. (1996). Automated system rapidly identifies and characterizes microorganisms in food. Food Techol January 1996, 77-81.

Combet-Blanc, Y., Ollivier, B., Streicher, C., Patel, B. K. C., Dwivedi, P. P., Pot, B., Prensier, G. \& Garcia, J.-L. (1995). Bacillus thermoamylovorans sp. nov., a moderately thermophilic and amylolytic bacterium. Int $J$ Syst Bacteriol 45, 9-16.

Demharter, W. \& Hensel, R. (1989). Bacillus thermocloaceae sp. nov., a new thermophilic species from sewage sludge. Syst Appl Microbiol 11, 272-276.

Heyndrickx, M., Lebbe, L., Kersters, K., De Vos, P., Forsyth, G. \& Logan, N. A. (1998). Virgibacillus: a new genus to accomodate Bacillus pantothenicus (Proom \& Knight 1950). Emended description of Virgibacillus pantothenicus. Int J Syst Bacteriol 48, 99-106.

Klaushofer, H. \& Hollaus, F. (1970). Zur taxonomie der hochthermophilen, in zuckerfabrikssaften vorkommenden aeroben sporenbildner. Z Zuckerind 20, 465-470.

Kurtzman, C. P., Johnson, C. J. \& Smiley, M. J. (1979). Determination of conspecificity of Candida utilis and Hansenula jadinii through DNA reassociation. Mycologia 71, 844-847. 
Lanyi, B. (1987). Classical and rapid identification: methods for medically important bacteria. Methods Microbiol 19, 1-67.

Manachini, P. L., Fortina, M. G., Parini, C. \& Craveri, R. (1985). Bacillus thermoruber sp. nov., nom. rev., a red-pigmented thermophilic bacterium. Int J Syst Bacteriol 35, 493-496.

Marmur, J. \& Doty, P. (1962). Determination of the base composition of deoxyribonucleic acid from its thermal denaturation temperature. J Mol Biol 5, 109-118.

Marteinsson, V. T., Birrien, J.-L., Jeanthon, C. \& Prieur, D. (1996). Numerical taxonomic study of thermophilic Bacillus isolated from three geographically separated deep-sea hydrothermal vents. FEMS Microbiol Ecol 21, 255-266.

Meier-Stauffer, K., Busse, H.-J., Rainey, F. A. \& 7 other authors (1996). Description of Bacillus thermoaerophilus sp. nov., to include sugar beet isolates and Bacillus brevis ATCC 12990. Int $J$ Syst Bacteriol 46, 532-541.

Mora, D., Fortina, M. G., Nicastro, G., Parini, C. \& Manachini, P. L. (1998). Genotypic characterization of thermophilic bacilli: a study on new isolates and several reference strains. Res Microbiol 149, 711-722.

Owen, R. J. \& Hill, L. R. (1979). The estimation of base composition, base pairing and genome sizes of bacterial deoxyribonucleic acid. In Identification Methods for Microbiologists, pp. 277-296. Edited by F. A. Skinner \& D. W. Lovelock. London: Academic Press.

Pettersson, B., Lembke, F., Hammer, P., Stackebrandt, E. \& Priest, F. G. (1996). Bacillus sporothermodurans, a new species producing highly heat-resistant endospores. Int J Syst Bacteriol 46 , 759-764.

Pichinoty, F., Durand, M., Job, C., Mandel, M. \& Garcia, J.-L. (1978). Etude morphologique, physiologique et taxonomique de Bacillus azotoformans. Can J Microbiol 24, 608-617.

Rainey, F. A., Fritze, D. \& Stackebrandt, E. (1994). The phylogenetic diversity of thermophilic members of the genus Bacillus as revealed by $16 \mathrm{~S}$ rDNA analysis. FEMS Microbiol Lett 115, 205-212.

Reischl, U., Emler, S., Horak, Z., Kaustova, J., Kroppenstedt, R. M., Lehn, N. \& Naumann, L. (1998). Mycobacterium bohemicum sp. nov., a new slow-growing scotochromogenic mycobacterium. Int J Syst Bacteriol 48, 1349-1355.
Rheims, H., Frühling, A., Schumann, P., Rohde, M. \& Stackebrandt, E. (1999). Description of Bacillus silvestris sp. nov., a new member of the genus Bacillus, containing lysine in its cell wall. Int J Syst Bacteriol 49, 795-802.

Sambrook, J., Fritsch, E. F. \& Maniatis, T. (1989). Molecular Cloning: a Laboratory Manual, 2nd edn. Cold Spring Harbor, NY : Cold Spring Harbor Laboratory.

Seidler, R. J. \& Mandel, M. (1971). Quantitative aspects of deoxyribonucleic acid renaturation: base composition, state of chromosome replication and polynucleotide homologies. $J$ Bacteriol 106, 608-614.

Shida, O., Takagi, H., Kadowari, K. \& Komagata, K. (1996). Proposal for two new genera, Brevibacillus gen. nov. and Aneurinibacillus gen. nov. Int J Syst Bacteriol 46, 939-946.

Smith, N. R., Gordon, R. E. \& Clark, F. E. (1952). Aerobic sporeforming bacteria. Agric Monogr 16. Washington, DC: US Department of Agriculture.

Sneath, P. H. A. \& Sokal, R. R. (1973). Numerical Taxonomy: the Principles and Practice of Numerical Classification. San Francisco: Freeman.

Sunna, A., Tokajian, S., Burghardt, J., Rainey, F., Antranikian, G. \& Hashwa, F. (1997). Identification of Bacillus kaustophilus, Bacillus thermocatenulatus and Bacillus strain HSR as members of Bacillus thermoleovorans. Syst Appl Microbiol 20, 232-237.

Walker, P.D. \& Wolf, J. (1971). The taxonomy of Bacillus stearothermophilus. In Spore Research, pp. 247-262. Edited by A. N. Barker, G. W. Gould \& J. Wolf. London: Academic Press.

White, D., Sharp, R. J. \& Priest, F. G. (1993). A polyphasic taxonomic study of thermophilic bacilli from a wide geographical area. Antonie Leeuwenhoek 64, 357-386.

Wisotzkey, J. D., Jurtshuk, P. J. R., Fox, G. E., Deinhard, G. \& Poralla, K. (1992). Comparative sequence analyses on the $16 \mathrm{~S}$ rRNA (rDNA) of Bacillus acidocaldarius, Bacillus acidoterrestris, and Bacillus cycloheptanicus and proposal for creation of a new genus, Alicyclobacillus gen. nov. Int J Syst Bacteriol 42, 263-269.

Zahner, V. \& Priest, F. G. (1997). Distribution of restriction endonucleases among some entomopathogenic strains of Bacillus sphaericus. Lett Appl Bacteriol 24, 483-487. 